\title{
A Review of the Major Varieties of English Language
}

\author{
Ligang $\operatorname{Han}^{1}$ \\ ${ }^{1}$ English Department, North China Electric Power University, Baoding City, Hebei Province, China \\ Correspondence: Ligang Han, English Department, North China Electric Power University, Baoding City, Hebei \\ Province, China. E-mail: liganghan@163.com
}

Received: November 27, 2018

doi:10.5539/ies.v12n2p93

\author{
Accepted: December 30, 2018 \\ Online Published: January 30, 2019 \\ URL: https://doi.org/10.5539/ies.v12n2p93
}

\begin{abstract}
English is clarified as a Germanic language, and it began in what is now the British-Isles. After years of development, English language has many varieties in different parts of the world. Different varieties differ in accent, vocabulary, grammar, discourse, sociolinguistics, and have its respective characteristics in pronunciation, tone, intonation, spelling and so on. Therefore, it is important for English language learners to observe the differences in language use. The present paper is an attempt to explore the regional characteristics of the two most commonly used varieties of the English Language-British English and American English. It is concluded that there will be intercommunications which will make the regional differences mild and easily understood. However, some differences may disappear, the others will remain so.
\end{abstract}

Keywords: English language, varieties, characteristics, differences

\section{Introduction}

English is not only known as the language of the English people, but also as the language spoken by people in many countries. English began in what is now the British-Isles. At the beginning of the fifth century, Britain was invaded by three tribes from Northern Europe: the Angles, Saxons and Jutes. These three tribes settled down on the island and merged into one people. The three dialects they spoke naturally grew into a single language, the English language.

English is clarified as a Germanic language. It is one of the languages related to German, Dutch, Norwegian and Swedish. Its history goes back to the year 450, when the old English is marked. The history of the English language is generally divided into three periods: Old English (450-1150), Middle English (1150-1500) and Modern English (1500-present) (Qin, 1983). The English language began with very small population. However, after years of development, now it is probably one of the most widely spoken languages in the world.

With the development of the English language, it has many varieties in different parts of the world. Different varieties differ in accent, vocabulary, grammar, discourse, sociolinguistics, and have its respective characteristics in pronunciation, tone, intonation, spelling and so on. Therefore, it is important for English language learners to observe the differences in language use.

\section{English and Englishes}

\subsection{The Development of English into Englishes}

English has changed in many ways. American English is one example. Early in the seventeenth century, some colonists landed in America, taking with them the Elizabethan English, the language used by Shakespeare and Milton. As time went on, the English language gradually changed on both sides of the Atlantic.

The Americans adopted many words from foreign languages and invented large numbers of new words to meet various needs. That is to say, English has developed a character of its own, reflecting the life and the physical and social movement of the American people. Just as Noah Webster (1789), the famous American lexicographer and author, wrote in his Dissertations on the English Language, "The reasons for American English being different from English English are simple: As an independent nation, our honor requires us to have a system of our own, in language as well as in government. Great Britain, whose children we are, and whose language we speak, should no longer be our standard..."

Because of the spreading of English to the world, there are changes that have occurred as a result of individuals who have come from different areas in England, who have moved around the world and taken with them their 
regional characteristics. Noticeably, there are South African English, New Zealand English, Australian English, Canadian English and the most commonly used British English and American English.

\subsection{What are British English and American English?}

Before the discussion of the two major varieties--British English and American English, it is important to get a clear understanding of what British English and American English are. It has already been pointed out that no two persons speak alike, and within the area of all but the smallest speech communities (groups of people speaking the same language) there are subdivisions of recognizably different types of language, called dialects, which do not, however, render intercommunication impossible or markedly difficult.

One speaks of different dialects of English (Southern British English, Northern British English, Scottish English, Midwest American English, New England American English and so on, with of course, many more delicately distinguished subdialects within these general categories), but no one would speak of Welsh and English or of Irish and English as dialects of a single language, although they are spoken within the same areas and often by people living in the same villages as each other (Robins, 1979).

Therefore, in a narrow sense, British English is the English spoken by the great majority of educated people in South and Southeast England, especially in London and its vicinity. American English is General American English that spoken by the great majority of the American people. In a broad sense, British English and American English refer to the two representative varieties of English language used by countries and regions as their native language, second language or one of the foreign languages.

From this sense, the discussion and research about British English and American English will help language learners better understand not only the English language used by Britain and the United States, but also the English used world-wide.

\section{Characteristics of British English and American English}

Because both British English and American English are just two varieties of the English language with their separate development according to historical, political and social changes, therefore, it is evident that there is no superiority or inferiority as regards British English and American English.

However, as a language learner, it is very important to observe the characteristics and differences in language use. That is the key to learn a language well. From three main aspects (phonetics, vocabulary and grammar), the following presents a brief comparison of the two most widely used varieties of English language.

\subsection{Differences in Phonetics}

\subsubsection{RP and GA}

In different period of English language development, the pronunciation varies. And even in one period, the pronunciation also varies in different regions of a country.

For example, the traditional way is to clarify American English into three types: Eastern American, Southern American and General American. Here, according to some linguists, the pronunciation of American English and British English refers to the General American (GA) and Received Pronunciation (RP).

\subsubsection{Differences in Individual Sounds}

Firstly, the most marked difference between GA and RP lies in the pronunciation of the vowels of dance, fast and glass. Americans pronounce these words with a sound $/ \mathfrak{a} /$ as in cat. In contrast, British people will pronounce these words as /da:ns/, /fa:st/ and /gla:s/.

Secondly, another noticeable difference can be found in the pronunciation of words like for, door and car. In America, these words are pronounced with $r$ sound as a fricative, whereas in England it is silent except in expressions like far away and the door opens when a linking $r$ is naturally inserted.

Thirdly, Americans pronounce words like dock, fog and hot with a low backsound /a/ like the vowel sound in car and father shortened. On the contrary, British people will pronounce it as $/ \mathcal{J} /$ sound.

Fourthly, in American English, words like dew, duke and new with the /ju:/ sound reduced to /u:/.

Finally, in American English, people traditionally speak out every syllable. However, in British English, people tend to omit some of the syllables. One case is that words ending with-ary or-ory in American English are pronounced as four-syllabled words, whereas in British English are pronounced as three-syllabled words.

\subsubsection{Differences in Stress}

It may be noted that word-stress is weaker in American English than in British English. Consequently, American 
speech is more monotonous, but at the same time is generally more distinct.

American English tends to put the stress on the first syllable but also to put a secondary stress on the later syllable and pronounces the remaining syllable more distinctly.

\subsection{Differences in Vocabulary}

\subsubsection{Differences in Spelling}

In dealing with the spelling of the vocabulary, there are some rules and regulations to follow.

Firstly, words ending with-er in American English have the ending as-re in British English. For example, in British English, theatre, centre, metre, fibre, litre are spelled as theater, center, meter, fiber, liter in American English (Some of the examples are taken from Lin, 1987).

Secondly, words ending with-or in American English as-our in British English. For example, in British English, colour, labour, honour, humour, favour are spelled as color, labor, honor, humor, favor in American English.

Thirdly, words having one consonant in American English whereas have two in British English. For example, in British English, traveller, waggon, jeweller, dialled are spelled as traveler, wagon, jeweler, dialed in American English.

Fourthly, words end with-se in American English have ending as-ce in British English. For example, in British English, defence, offence, licence are spelled as defense, offense, license in American English.

Fifthly, words ending with-ize or-yze in American English normally spell as-ise or-yse in British English. For example, in British English, analyse, memorise, organise, recognise are spelled as analyze, memorize, organize, recognize in American English. However, more and more British people tend to use the American way of spelling.

Besides what is discussed above, there are other differences in spelling. For example, in British English, axe, cheque, draught, grey, plough, tyre are spelled as ax, check, draft, gray, plow, tire in American English.

From the discussion above, it is easy to draw the conclusion about one distinctive characteristic of the American English. That is to say, American English is more 'English' in accordance with the rules and regulations of the Modern English pronunciation and spelling systems. For example, in Modern English, the sound $/ \partial /$ represents what-er sounds as the ending letters in words like center, meter, fiber, etc. Whereas in British English, people would spell differently with the /a/ sound. They will spell as centre, metre, fibre (Lin, 1987). There are more of these words:

$$
\begin{array}{lll} 
& \text { BrE } & \text { AmE } \\
|f| & \text { draught } & \text { draft } \\
\text { laul } & \text { plough } & \text { plow } \\
\mid k / & \text { cheque } & \text { check }
\end{array}
$$

\subsubsection{The Same Meaning Using Different Word Items}

Due to the differences in the population structure, physical environment, social and economic conditions, some of the vocabulary in American English rightly remain its meaning just as what the first settlers brought into the land. So these words still have the meaning as in the history of British English period. However, British English also develops in its course of history. For instance,

Mad for angry, mad is a survival of thirteenth century English. Sick for ill, sick appeared in the ninth century and was replaced by ill in the fifteenth century. Sidewalk for pavement, sidewalk is an old word first coined in the eighteenth century. Fall for autumn. Fall is also a survival of the older British usage (Lin, 1987).

Therefore, conservation and innovation are two major features of American English. On the one hand, American English has preserved certain older features of the language, which have disappeared from British English. A number of survivals of British English mentioned above represent conservation of the American vocabulary. On the other hand, American English is characterized with the frontier spirit, ingenuity, vividness and casualness.

The followings are some common words indicating the same meaning.

$\begin{array}{cc}\mathrm{BrE} & \mathrm{AmE} \\ \text { lift } & \text { elevator } \\ \text { tap } & \text { faucet } \\ \text { flat } & \text { apartment }\end{array}$




$\begin{array}{cc}\text { sweets } & \text { candy } \\ \text { biscuit } & \text { cracker } \\ \text { petrol } & \text { gas } \\ \text { film } & \text { movie } \\ \text { lorry } & \text { truck } \\ \text { underground } & \text { subway }\end{array}$

Strevens (1972) devised two contrasting word-lists in his book British and American English. These two word-lists contain several hundred common equivalents.

With the development of modern telecommunication technology, the world is becoming a global village. Thus the intercommunication between the United States and England makes a lot of those words listed above interchangeable. But as British English and American English have many sources of word formation, it is doubtless that the difference will remain so.

\subsubsection{One Word Item Having Different Meanings}

There is a story used to be told to illustrate the theme that the US and Britain are divided by a common language.

This story took place during the latter stages of the Second World War at the supreme allied headquarters. When on one particular day, a British general telephoned his American counterpart. In those days, telephone was connected by a human operator. And when she finally put the call through, the British general was beginning to speak to his American opposite number, she broke in on the conversation and said to the British general, "Are you through General?" and he said, "Yes". So she cut him off immediately. For the word "through", what the British General understood is "connected". However, the operator thought as "finished".

That is one example illustrating the differences in word understanding that causes people problems. There are more of these words.

$\begin{array}{ccc} & \mathrm{BrE} & \mathrm{AmE} \\ \text { billion } & \text { value in powers of ten } 10^{12} & 10^{9} \\ \text { first floor } & \text { second floor } & \text { ground floor } \\ \text { corn } & \text { wheat } & \text { maize } \\ \text { saloon } & \text { automobile of the sedan type } & \text { bar }\end{array}$

\subsection{Differences in Grammar}

Compared with phonetics and vocabulary, grammatical differences are generally few and trivial. It is not only because the grammar element is the most stable part in the language development, but also that the formation of the American English grammar was quite well developed as the seventeenth British English grammar. Therefore, only because American English has a character of creativeness, thus it results in some subtle differences in grammar between British English and American English. Non-native speakers should understand these small differences in order to use them correctly.

\subsubsection{Differences in Verb Usage}

British and American English use the phrase "Do you have ..." but with different meanings. In American English "Do you have ..." means "Do you possess at this moment of time?" However, in British English "Do you have ..." means "Do you habitually have?" For British English, it uses a different pattern to express the equivalent meaning as the American English. For instance,

\section{Do you have a dictionary? (AmE)}

Have you a Dictionary? (BrE)

\section{I don't have any money. (AmE)}

\section{I haven't any money. (BrE)}

It's not that the British do not use the auxiliary $d o$ with the negative. They do, in fact, use it. But there is a different register in British English, which is a more formal register or more educated register.

In British English the verb get has its past participle got, while American English speakers use gotten as its past participle. For example: 
I wish I could have gotten here sooner. (AmE)

I wish I could have got here sooner. (BrE)

Actually, there are more verbs in American English that have different past participles from British English. For instance,

$\begin{array}{ccc}\text { Verb } & \text { past participle of BrE } & \text { p.p. of both BrE and AmE } \\ \text { burn } & \text { burnt } & \text { burned } \\ \text { learn } & \text { learnt } & \text { learned } \\ \text { smell } & \text { smelt } & \text { smelled } \\ \text { spoil } & \text { spoilt } & \text { spoiled }\end{array}$

3.3.2 Differences in the Use of the Relative Clause Marker

In American English, people tend to use the word that, for example:

I saw the man that arrived from Italy yesterday.

That refers to the man who arrived from Italy yesterday. In varieties of British English, it's not unusual to find that replaced by which. For example:

Please hand me the coffee cup, which is over to the left side of the table.

Or: Please hand me the coffee cup to the left side of the table. (with no marker at all)

3.3.3 Differences in the Use of Preposition and Article

In American English, people generally do not use the preposition on before a day of the week or a specific date, while in British English people do use it. For example,

She started her vocation Monday. (AmE)

She started her vocation on Monday. (BrE)

There are also some other examples in American English where people omit some of the prepositions in some phrases. However, in British English, people do not. For example (some examples are taken from Lin, 1987),

Is he home? (AmE)

Is he at home? (BrE)

I feel guilty because I haven 't written her lately. (AmE)

I feel guilty because I haven't written to her lately. (BrE)

On the contrary, Americans tend to use the definite article the more often than in British English.

The patient was in the hospital. (AmE)

The patient was in hospital. (BrE)

\subsubsection{Other Different Usage}

Because there are not tremendous differences in grammar between British English and American English, and also there is no very clear rule and regulation to follow, it is much easier to understand with examples. Compare the following pairs of sentences (some examples are taken from Lin, 1987):

One should do his best for his motherland. (AmE)

One should do one's best for one's motherland. (BrE)

I will plant more trees tomorrow. (AmE)

I shall plant more trees tomorrow. (BrE)

I insist that you go. (AmE)

I insist that you should go. (BrE)

You'd better go see a doctor about the fever. (AmE)

You'd better go and see a doctor about the fever. (BrE)

Who is this? I don't recognize your voice. (AmE)

Who is that? I don't recognize your voice. (BrE) 
It's just a few minutes after six. (AmE)

It's just a few minutes past six. (BrE)

Before I realized what had happened, the car was gone. (AmE)

Before I realized what had happened, the car had gone. (BrE)

On weekends, I like to get my mind off my work by reading interesting books. (AmE)

At weekends, I like to take my mind off my work by reading interesting books. (BrE)

I enclosed some pictures in my letter. (AmE)

I enclosed some photographs with my letter. (BrE)

\subsection{Other Subtle Differences}

When writing the address, there is a different formula between British English and American English. For instance, in marking the date:

September 13(th), 1998; or 9/13/1998 (AmE)

13(th) September, 1998; or 13/9/1998 (BrE)

In spite of all the above differences between British English and American English, it should be noted that unifying factors outweigh splitting factors and that there are potent forces at work bringing the two main streams of English closely together.

American and British scholars are stepping up their cooperation in the writing of composite books addressed to the English-speaking countries and the councils of learned societies have taken steps to standardize technical terminology. The ubiquity of radio, television and Internet, the interchange of films, novels, journals, plays and the presence of communication satellites--all serve to make the divergence narrower and narrower.

\section{British English and American English in the Future}

Although there are some differences in phonetics, vocabulary and grammar between British English and American English as discussed above, the basics of the phonetic system, word stock and grammar still make it clear that British English and American English are just two regional varieties of one language, not two different languages.

However, both British English and American English have developed their own characteristics in their historical development. Many believe that those small differences will rightly remain so and will not disappear. The rapid development of modern science, technology, mass media and constant cultural and economic exchanges between the two nations will make those differences mild and easily understood.

That is to say, for a language learner, there should be no difficulty in understanding the other variety if he has learned either British English or American English. But a good understanding of the differences will definitely help in using the English language.

\section{Conclusion}

The present paper is an attempt to explore the differences between the two most commonly used varieties of the English Language-British English and American English.

Firstly, it is difficult to discuss the current state of anything without reference to its history. Therefore from the brief account of the historical development of the English language, it is clear to know that British English and American English are just two regional varieties, not two different languages.

Secondly, as a language learner, it is important to observe the differences in language use. That is the key to learn a language well. This also applies to the study of English. The most remarkable difference between British English and American English lies on vocabulary. Also there are some subtle differences in phonetics, grammar and other habitual usage.

Thirdly, from the differences discussed, it is important to notice that the American English is more 'English' in accordance with the pronunciation and spelling systems.

Finally, as to the future development of British English and American English is easy to draw the conclusion that there will be intercommunications which will make the differences mild and easily understood. However, some differences may disappear, the others will remain so.

\section{References}

Brown, H. D. (2002). Principles of language learning and teaching. Beijing: Foreign Language Teaching and 
Research Press.

Byram, M. (Ed.). (2000). Routledge encyclopedia of language teaching and learning. London: Routledge.

Gui, C. K. (1985). Applied phonology of American English. Shanghai: Shanghai Foreign Language Education Press.

Gwinn, R. P., \& Norton, B. P. (1993). The new encyclopedia Britannica. Chicago: Encyclopedia Britannica Inc.

Harmer, J. (2007). The practice of English language teaching. Harlow: Pearson Education Limited.

Hou, W. R. (1983). British English and American English. Shanghai: Shanghai Foreign Language Education Press.

Hou, W. R. (1988). Varieties of English. Shanghai: Shanghai Foreign Language Education Press.

Lightbown, P. M., \& Spada, N. (2002). How languages are learned. Shanghai: Shanghai Foreign Language Education Press.

Lin, C. Z. (1987). An introduction to English lexicology. Wuhan: Wuhan University Press.

Lu, G. Q. (1983). Modern English lexicology. Shanghai: Shanghai Foreign Language Education Press.

Qin, X. B. (1983). A brief history of the English language. Changsha: Hunan Education Press.

Robins, R. (1979). A short history of linguistics. London: Longman.

Strevens, P. (1972). British and American English. London: Collier Macmillan Publishers.

Webster, N. (1789). Dissertations on the English language. Boston: Isaiah Thomas and Company.

\section{Copyrights}

Copyright for this article is retained by the author(s), with first publication rights granted to the journal.

This is an open-access article distributed under the terms and conditions of the Creative Commons Attribution license (http://creativecommons.org/licenses/by/4.0/). 